\title{
Flora roślin synantropijnych biotopów miejskich Olsztyna
}

\author{
Flora of synanthropic plants of urban biotopes in Olsztyn
}

\section{Bartosz Tomaszewski $\bowtie$}

\author{
Instytut Hodowli i Aklimatyzacji Roślin - Państwowy Instytut Badawczy, Ogród Botaniczny Krajowego Centrum \\ Roślinnych Zasobów Genowych, ul. Jeździecka 5, 85-687 Bydgoszcz \\ $\triangle$ b.tomaszewski@ihar.edu.pl
}

\begin{abstract}
Na terenie biotopów miejskich Olsztyna zebrano 14950 not florystycznych i stwierdzono występowanie 578 gatunków naczyniowych roślin zielnych oraz siewek drzew i krzewów, a liczba gatunków w polach podstawowych (kwadratach o boku $1 \mathrm{~km}$ ) wahała się od 18 (kwadraty 67 i 76 EB42) do 210 gatunków (kwadrat 35 EB52). Flora synantropijna Olsztyna liczyła 84 rodziny, z których najbardziej zasobne w gatunki są: Asteraceae, Poaceae, Brassicaceae i Fabaceae (odpowiednio 78, 51, 39 i 38 gatunków). Najbardziej rozpowszechnioną formą życiową roślin na terenie zurbanizowanych obszarów miasta Olsztyna były hemikryptofity, które stanowiły ponad $40 \%$ analizowanej flory. Najliczniej reprezentowaną grupą geograficzno-historyczną we florze biotopów miejskich Olsztyna były gatunki synantropijne miejscowego pochodzenia, czyli apofity, z wyraźną dominacją apofitów leśnych i zaroślowych. Wśród gatunków obcych, to jest antropofitów, dominowały diafity, czyli gatunki nie zadomowione trwale. Występowanie oraz przestrzenne rozmieszczenie poszczególnych gatunków roślin w Olsztynie w wydzielonych na jego obszarze kompleksach użytkowania przestrzeni ukazało wyraźną liczebną przewagę gatunków roślin w kompleksie transportowym. Stwierdzono tam występowanie 466 gatunków roślin, co stanowiło ponad 80\% wszystkich zidentyfikowanych taksonów. Największą liczbę gatunków na obszarze biotopów miejskich Olsztyna zanotowano w obrębie tych reprezentujących na skali hemerobii stopień H4, który obejmował siedliska przejściowe od mezodo $\beta$-euhemerobowych. Pola podstawowe (kwadraty) były zróżnicowane pod względem takich wskaźników jak walor florystyczny czy odrębność florystyczna oraz wskaźników: synatropizacji, modernizacji i labilności flory. Najwyższą wartość waloru florystycznego jak i odrębności florystycznej stwierdzono w przypadku kwadratu 26 (EB 52). Największe wartości współczynnika synantropizacji stwierdzono w kwadratach 35 (EB 52), 26 (EB 52) oraz 89 (EB 42) - 58. Najmocniejszą korelację dodatnią stwierdzono pomiędzy walorem florystycznym a liczbą gatunków oraz procentowym udziałem antropofitów w analizowanych kwadratach. W obu przypadkach współczynnik korelacji rang Spearmana był wysoki i wynosił 0,999 .
\end{abstract}

Słowa kluczowe: synantropizacja, flora miasta, apofity, antropofity

The 14950 floristic data were collected on the urban biotops area in Olsztyn. There were 578 species of the vascular herbaceous plants and seedlings of trees and shrubs. Number of species in the basic area (square units $1 \times 11 \mathrm{~km}$ ) was from 18 (squares 67 and 76 (EB42) to 210 (square 35 (EB52). The synanthropic flora of Olsztyn included 84 families, of which the most abundant species are: Asteraceae, Poaceae, Brassicaceae and Fabaceae (78, 51, 39 and 38 species respectively). The most common life form of plants in the urbanized areas of Olsztyn were hemicryptophytes which constituted over $40 \%$ of the flora analyzed. The most numerously represented geographical and historical group in the flora of the urban biotopes of Olsztyn were synanthropic species of local origin, i.e. apophytes, with a clear domination of forest and scrub apophytes. Among the alien species, i.e. anthropophytes, diaphytes dominated, i.e. species that were not permanently established. The occurrence and spatial distribution of particular plant species in Olsztyn in spatial use complexes separated on its area showed a clear numerical predominance of plant species in the transport complex. There were found 466 plant species, which constituted more than $80 \%$ of all identified taxa. The greatest number of species in the Olsztyn urban biotopes was recorded within those representing the H4 degree on the hemerobic scale, which included transitional habitats from meso- to $\beta$-euhemerobic. Basic fields (squares) were differentiated in terms of such indices as floristic value or floristic distinctness and the indices of: synatropization, modernization and labile flora. The highest value of floristic value and floristic distinctness was found in case of square 26 (EB 52). The highest values of synanthropization coefficient were found in quadrats 35 (EB 52), 26 (EB 52) and 89 (EB 42) -58 . The strongest positive correlation was found between floristic value and number of species and percentage share of anthropophytes in the analyzed quadrats. In both cases Spearman's rank correlation coefficient was high at 0.999 .

Key words: synanthropization, urban flora, apophytes, anthropophytes 


\section{Wstęp}

Synantropizacja szaty roślinnej jest to całokształt historycznych oraz współczesnych przeobrażeń roślinności pod wpływem presji i działalności człowieka (Faliński 1966a, 1966b, Kornaś 1981, Olaczek 1982). Zagadnienie to od połowy XX wieku wysuwa się na czoło zagadnień geobotanicznych. Współcześnie procesy synantropizacyjne ulegają znacznemu nasileniu, czego skutkiem jest często wymieranie całych grup gatunków, a w przypadku roślin obcego pochodzenia dochodzi do inwazji o trudnych do przewidzenia konsekwencjach. Do najważniejszych przyczyn tego zjawiska zalicza się urbanizację. Na przełomie wieków miasto stało się najsilniej rozwijającą się jednostką terytorialną na świecie. Rozprzestrzenianie się miast (urban sprawl) jest procesem złożonym i nieuniknionym (Nuissl H. i in. 2005). Urbanizacja pociaga za soba antropopresję nie tylko na terenie samych miast i aglomeracji, ale nasila się ona także w obszarach podmiejskich, dotąd bardziej lub mniej naturalnych, zajmowanych przez dobrze funkcjonujące zbiorowiska flory i fauny. Dynamika procesu urbanizacji nadal się zwiększa, co powoduje wzrost zagęszczenia populacji ludzkiej w miastach i dalszy rozwój infrastruktury miejskiej. Pociąga to za sobą spadek udziału na tych terenach ekosystemów leśnych, łąkowych, agrocenoz i innych terenów zieleni (Zimny 2005).

Chociaż Olsztyn jest miastem o wielowiekowej tradycji, jednak jego zasoby florystyczne nie są dostatecznie poznane. Nieliczne dane dotyczące występowania niektórych rzadszych gatunków roślin synantropijnych na omawianym obszarze można znaleźć w szerszych opracowaniach florystycznych i fitosocjologicznych Abromeita i in. (1898 - 1940) i Steffena (1931, 1940), które swoim zasięgiem obejmują cały obszar byłych Prus Wschodnich. Podobne fakty o występowaniu rzadszych i ciekawszych gatunkach synantropijnych znalazły miejsce w pracach Olesińskiego (1968), Korniaka (1968a, 1968b) oraz Olesińskiego i Korniaka (1980). Pojawiły się też opracowania Stypińskiego (1978, 1988, 1995) dotyczące dendroflory miasta, a także praca Endlera i in. (1999) zawierająca wiadomości o niektórych roślinach związanych ze zbiorowiskiem Chelidonio-Robinietum w parkach Olsztyna. Dane o występowaniu kilkunastu gatunków najbardziej narażonych na mechaniczne ugniatanie gleby zawiera też praca doktorska Kalinowskiej (2004). Pewnych wiadomości o występowaniu synantropijnych roślin na terenie miasta $\mathrm{w}$ ostatnim okresie dostarcza praca doktorska Pieczyńskiej (2006) przedstawiająca występowanie i zmienność północnoamerykańskich gatunków z rodzaju nawłoć (Solidago ssp.).

Celem niniejszej pracy jest przedstawienie flory naczyniowych roślin zielnych oraz siewek drzew i krzewów na tle biotopów miejskich Olsztyna.

\section{Charakterystyka terenu badań}

Według regionalizacji fizyczno-geograficznej miasto usytuowane jest $\mathrm{w}$ prowincji Niżu Zachodniorosyjskiego, podprowincji Pojezierzy Wschodniobałtyckich, makroregionie Pojezierze Mazurskie, mezoregionie Pojezierze Olsztyńskie (Kondracki 1988, 1994, 2002). Cały obszar Polski północno-wschodniej, obejmujący swym zasięgiem również teren Olsztyna, został ukształtowany w wyniku działalności plejstoceńskiego lodowca skandynawskiego. Według koncepcji Galona (1972) jedną z wielu wyróżnionych na tym obszarze stref morfogenetycznych jest falisty garb pojezierny ściśle związany z pomorską fazą Zlodowacenia Bałtyckiego. Jedną $\mathrm{z}$ odrębnych jednostek w jego obrębie jest Pojezierze Olsztyńskie, rozciągające się po obydwu stronach górnego biegu rzeki Łyny i stanowiące zachodnią część Pojezierza Mazurskiego (Jutrzenka-Trzebiatowski 1999). Zasięgiem swym odpowiada ono wyodrębniającemu się podczas ostatniego zlodowacenia bocznemu płatowi lodowcowemu, nazywanemu lobem Łyny. Poszczególne etapy jego recesji zaznacza siedem koncentrycznych łuków morenowych. Osią ich symetrii jest Łyna płynąca w Olsztynie na wysokości 98 m n.p.m. (Kondracki 1994).

Według Wosia (1999) Olsztyn zaklasyfikować można do Regionu Zachodniomazurskiego (R-X). Region ten charakteryzuje się częstym występowaniem dni umiarkowanie ciepłych z dużym zachmurzeniem ogólnym nieba i niedużym opadem atmosferycznym. Średnia roczna temperatura w rejonie Olsztyna wynosi około $7^{\circ} \mathrm{C}$. Najniższe temperatury $\mathrm{z}$ wielolecia notowane są w styczniu i lutym (ok. $3,9^{\circ} \mathrm{C}-4,2^{\circ} \mathrm{C}$ ), a najwyższe - w czerwcu, lipcu i sierpniu (około: $16,1^{\circ} \mathrm{C}$ $-16,9^{\circ} \mathrm{C}$ ). Średnia liczba dni gorących (powyżej $25^{\circ} \mathrm{C}$ ) wynosi 26. Średnia liczba dni mroźnych (poniżej $0^{\circ} \mathrm{C}$ ) wynosi około 50. Roczne sumy opadów wynoszą średnio około $600 \mathrm{~mm}$. Największe są latem (w lipcu około $90 \mathrm{~mm}$ ), a najmniejsze zimą i wczesną wiosna (styczeń - kwiecień; około $26-32 \mathrm{~mm}$ ). Dni z opadem jest około $160 \mathrm{w}$ roku. Pokrywa śnieżna utrzymuje się średnio około 106 dni w roku. Najwięcej dni pochmurnych występuje późną jesienią (w grudniu), a najmniej późnym latem (we wrześniu). Zachmurzenie generalnie jest większe w okresie późnej jesieni i zimą, mniejsze 
w pozostałych porach roku.

Zgodnie $\mathrm{z}$ podziałem administracyjnym Polski z roku 1998 Olsztyn jest stolicą województwa warmińsko-mazurskiego. Położony jest $\mathrm{w}$ podregionie olsztyńskim regionu północnego oraz posiada prawa powiatu. W roku 2006 miasto zamieszkiwało prawie 175 tysięcy osób (dane Urzędu Statystycznego w Olsztynie). Obecnie widoczny jest dalszy rozwój miasta - szybka rozbudowa dzielnic i powstawanie nowych osiedli mieszkaniowych, a także rozwój gałęzi przemysłowych, głównie w sektorze oponiarskim, drzewnym i meblarskim. Miasto nie posiada obwodnicy, a większość ruchu tranzytowego odbywa się jego ulicami. Olsztyn jest ważnym węzłem kolejowym regionu i obecnie posiada trzy funkcjonujące dworce kolejowe - Olsztyn Główny, Olsztyn Zachodni oraz Olsztyn Gutkowo. Jako jedno z niewielu miast polskich posiada dodatni współczynnik przyrostu naturalnego jak też dodatnie saldo migracji.

\section{Material i metody}

W badaniach nad współczesną florą Olsztyna zastosowano metodę kartowania stanowisk wszystkich gatunków w siatce jednakowych pól podstawowych - kwadratów o boku 1 km (ryc. 1.).

Jako podkład kartograficzny wykorzystano aktualny plan miasta, który opracowany został na bazie mapy w skali 1:18000. Podział miasta na podstawowe pola badawcze nawiązuje do siatki kwadratów stosowanej w, ,Atlasie rozmieszczenia roślin naczyniowych w Polsce" (Zając i Zając 2001). Jako podstawę przyjęto granice tzw. małych kwadratów (10 x $10 \mathrm{~km}$ ), w których zawiera się obszar Olsztyna. Jednostki te podzielono na 100 jednakowych pól, określając ich współrzędne według zasady wprowadzonej przez autorów koncepcji ATPOL-u.

Zgodnie $\mathrm{z}$ przyjętą procedurą na badanym terenie znalazły się 103 kwadraty, w tym 73 pola w całości leżące na obszarze Olsztyna oraz 30 pól przygranicznych, wysuniętych częściowo poza teren badań (przynajmniej w 25\% położonych w granicach miasta).

Badania terenowe polegały na dokumentowaniu składu florystycznego poszczególnych kwadratów z uwzględnieniem skali hemerobii siedlisk zajmowanych przez wszystkie gatunki. Dla każdego kwadratu wykonano spis florystyczny w optymalnym okresie sezonu wegetacyjnego, przy czym spis ten uzupełniano w innych fazach rozwoju fenologicznego. Na podstawie tych spisów powstawały noty florystyczne (sumy wystąpień gatunków w poszczególnych kwadratach = notowania) w liczbie 14950.

Nomenklaturę taksonów oraz układ systematyczny gatunków i rodzin podano za Mirkiem i in. (2002).

W opracowaniu flory biotopów miejskich Olsztyna frekwencja wystąpień taksonów odnoszona jest do liczby pól podstawowych (kwadratów o powierzchni $\left.1 \mathrm{~km}^{2}\right)$. Klasy frekwencji $\left(\mathrm{K}_{\mathrm{F}}\right)$ opierają się na wyznaczonych przedziałach współczynnika frekwencji (F) (tab. 1.)

Przynależność poszczególnych gatunków roślin synantropijnych do grup geograficzno-historycznych ustalono w oparciu o koncepcje Kornasia (1968a, 1968b, 1977), zmodyfikowane przez Mirka (1981). Dodatkowo korzystano z prac Jackowiaka (1990, 1998), Wołkowyckiego (2000) i Mirka

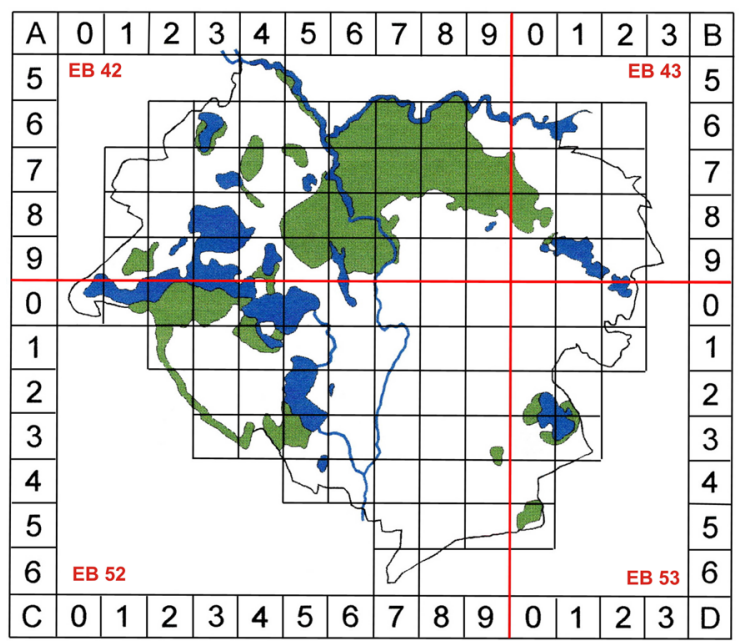

Ryc. 1. Podzial terenu na podstawowe pola badawcze - kwadraty o boku długości 1 km.

Fig. 1. Subdivision of the site into basic study fields - squares with side length of $\mathbf{1} \mathbf{~ k m}$. 
Tabela 1.

Klasy frekwencji gatunków $\left(K_{F}\right)$ na badanym terenie

Species frequency classes $\left(K_{F}\right)$ in the study area

\begin{tabular}{clcc}
\hline & $\begin{array}{c}\text { OKREŚLENIE FREKWENCJI } \\
\text { TAKSONÓW } \\
\text { DETERMINING THE FREQUENCY } \\
\text { OF TAXA }\end{array}$ & $\begin{array}{c}\text { WSPÓLCZYNNIK FREKWENCJI } \\
\text { (F) [\%] } \\
\text { ATTENDANCE RATIO (F) } \\
\text { [\%] }\end{array}$ & $\begin{array}{c}\text { LICZBA STANOWISK } \\
\text { NUMBER OF POSITIONS }\end{array}$ \\
\hline I & Bardzo rzadki & $<5$ & $1-5$ \\
II & Rzadki & $5,1-15$ & $6-15$ \\
III & Dość częsty & $15,1-30$ & $16-30$ \\
IV & Częsty & $30,1-60$ & $31-60$ \\
V & Pospolity & $>60,1$ & $61-103$ \\
\hline
\end{tabular}

i in. (2002). Przynależność poszczególnych gatunków do określonych form życiowych Raunkiaera (Kornaś, Medwecka-Kornaś 2002) przyjęto za Zarzyckim i in. (2002).

Podczas badań terenowych zwrócono uwagę na aktualny stan wykorzystania przestrzeni na obszarze miasta. Uwzględniając formy zagospodarowania terenu wydzielono następujące jednostki (kompleksy) przestrzenne: kompleks miejskich nekropolii (CM), kompleks luźnej (blokowej) zabudowy (KLBZ), kompleks zwartej (kamienicznej) zabudowy (KZKZ), kompleks willowy (KW), kompleks rolniczy (KR), kompleks transportowy (KT), kompleks parków miejskich (P), kompleks Aeroklubu Warmińsko-Mazurskiego na Dajtkach (L).

Ogólna koncepcja hemerobii rozumiana jest jako całościowa miara wpływu kulturowego na ekosystemy i obejmuje ogół skutków, które pojawiają się w nich zarówno w wyniku zamierzonej, jak i niezamierzonej ingerencji człowieka. Skala hemerobii określa zakres, intensywność oraz trwałość zmian zachodzących w ekosystemach pod wpływem działalności człowieka. Stopień skali hemerobii wzrasta wraz ze wzrostem antropopresji. W pracy przyjęto 9-stopniową skalę Kowarika (1988), obejmującą 5 stopni podstawowych i 4 przejściowe (Jackowiak 1998). W związku z przedmiotem badań niniejszego opracowania, którym są biotopy stricte miejskie Olsztyna, przynajmniej z minimalną antropopresją, skala hemerobii dla badanych siedlisk rozpoczyna się od stopnia mezohemerobowego (nie stwierdzono siedlisk a- oraz oligohemerobowych), a kończy stopniem polyhemerobowym.

\section{Wyniki}

$\mathrm{Na}$ obszarze biotopów miejskich Olsztyna

stwierdzono występowanie 578 gatunków naczyniowych roślin zielnych oraz siewek drzew i krzewów, w tym $5 \mathrm{w}$ randze podgatunku, reprezentujących 84 rodziny i 327 rodzajów. Zebrano 14950 not florystycznych.

Gatunki roślin synantropijnych Olsztyna należą do 84 rodzin. Najbardziej zasobnymi w gatunki rodzinami są: Asteraceae (78 gatunków, 14\%), Poaceae (51 gatunków, 9\%), Brassicaceae (39 gatunków, 7\%) i Fabaceae (38 gatunków, 7\%) (tab. 2.). W przypadku 64 rodzin liczba gatunków nie przekraczała 5 .

Liczebny rozkład taksonów w wydzielonych klasach frekwencji jest zgodny $\mathrm{z}$ uniwersalną prawidłowością: najliczniejszą grupę stanowią taksony bardzo rzadkie, a najmniej liczną taksony pospolite. Wśród wszystkich zidentyfikowanych gatunków ponad połowę stanowiły gatunki bardzo rzadkie, zajmujące od 1 do 5 stanowisk. Około 20\% stanowiły gatunki rzadkie. Stwierdzono podobną liczebność gatunków dość częstych i częstych. Obydwie grupy stanowiły po około $10 \%$ całej puli gatunków. Niewiele mniej było gatunków pospolitych - 9\% (tab. 3.). Gatunki najpospolitsze obserwowano w następującej liczbie pól podstawowych (kwadratów): Poa annua -102, Plantago major 102, Artemisia vulgaris - 101, Dactylis glomerata - 100, Taraxacum officinale - 99, Achillea millefolium - 96, Polygonum aviculare - 96, Trifolium repens - 95, Trifolium pratense - 92, Melandrium album - 90, Urtica dioica - 90.

Najbardziej rozpowszechnioną formą życiową roślin na terenie zurbanizowanych obszarów miasta są hemikryptofity. W liczbie 250 gatunków stanowią one prawie połowę analizowanej flory (ryc. 2.). Ponad 30\% - 176 gatunków - stanowią terofity. Kolejną liczebnie formą życiową są geofity z 58 gatunkami, które stanowią $10 \%$ całej flory synantropijnej. Bardzo zbliżony do siebie udział 
Frekwencja rodzin na obszarze biotopów miejskich Olsztyna

Frequency of families in the urban biotopes of Olsztyn

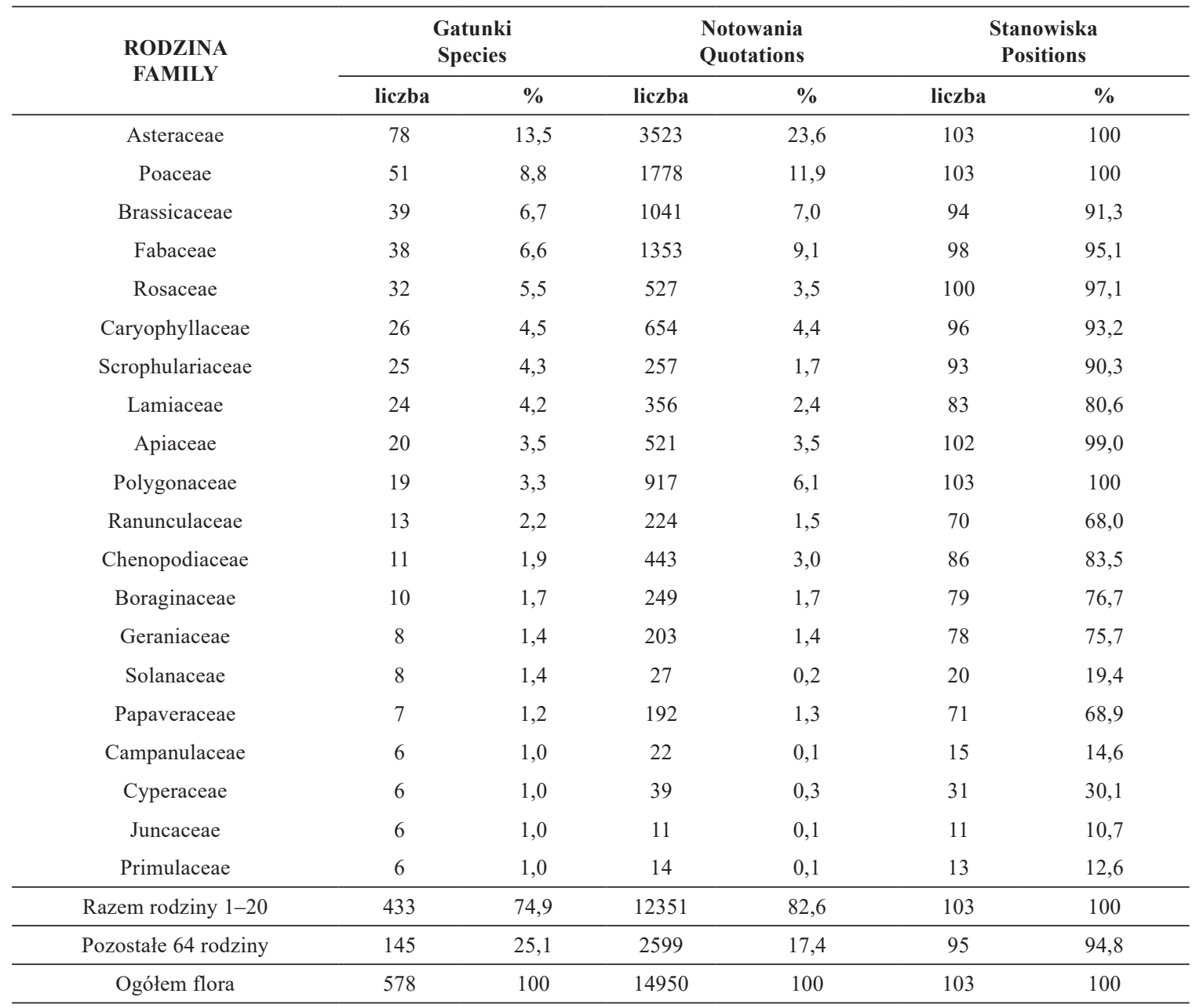

Tabela 3.

Udział gatunków w poszczególnych klasach frekwencji

Share of species in each attendance class

\begin{tabular}{|c|c|c|c|c|c|c|c|c|c|c|}
\hline & \multicolumn{10}{|c|}{$\begin{array}{l}\text { FREKWENCJA } \\
\text { FREQUENCY }\end{array}$} \\
\hline & \multicolumn{2}{|c|}{$\begin{array}{l}\text { Bardzo rzadki } \\
\text { Very rare }\end{array}$} & \multicolumn{2}{|c|}{$\begin{array}{l}\text { Rzadki } \\
\text { Rare }\end{array}$} & \multicolumn{2}{|c|}{$\begin{array}{l}\text { Dość częsty } \\
\text { Quite common }\end{array}$} & \multicolumn{2}{|c|}{$\begin{array}{c}\text { Częsty } \\
\text { Frequent }\end{array}$} & \multicolumn{2}{|c|}{$\begin{array}{l}\text { Pospolity } \\
\text { Common }\end{array}$} \\
\hline & Liczba & $\%$ & Liczba & $\%$ & Liczba & $\%$ & Liczba & $\%$ & Liczba & $\%$ \\
\hline Gatunki & 301 & 52,1 & 110 & 19,0 & 59 & 10,2 & 56 & 9,7 & 52 & 9,0 \\
\hline
\end{tabular}

przedstawiają mega- i nanofanerofity (reprezentowane przez samosiewy drzew i krzewów) - odpowiednio 28 i 35 gatunków. Najmniej jest chamefitów drzewiastych (5 gatunków), hydrofitów (4 gatunki) i lian (2 gatunki).

Najliczniej reprezentowaną grupą geograficzno -historyczną we florze biotopów miejskich Olsztyna są apofity, czyli gatunki synantropijne miejscowego pochodzenia. Na badanym terenie stwierdzono występowanie 336 gatunków apofitów, co stanowi $58 \%$ całej flory miejskiej Olsztyna (ryc. 3.).

Spośród wszystkich apofitów prawie $50 \%$ stanowią apofity leśne i zaroślowe (ryc. 4.), najliczniej reprezentowane przez takie gatunki, jak: Plantago major, Artemisia vulgaris, Aegopodium podagraria, Urtica dioica czy Tussilago farfara. 
Dość liczną grupę (25\%) stanowiły apofity łąkowe. W tej grupie roślin dominowały: Taraxacum officinale, Poa annua, Polygonum aviculare, Trifolium repens i Dactylis glomerata. Niewiele ponad $10 \%$ reprezentują apofity muraw kserotermicznych - Convolvulus arvensis, Berteroa incana, Bromus inermis - oraz nadwodne - Chenopodium album, Potentilla anserina czy Elymus repens. Najmniej $(9 \%)$ jest apofitów wydm i piaszczysk. Dominującą formą życiową wśród apofitów są hemikryptofity, czyli rośliny naziemnopączkowe. Reprezentowane są one przez 188 gatunków i stanowią ponad połowę (57\%) całej flory apofitów. Drugą co do liczebności formą są rośliny jednoroczne, czyli terofity. Udział gatunków tej grupy wynosił 18\% (61 gatunków). Najmniejszy udział stanowiły chamefity zielne.

Gatunki obce (antropofity) stanowią niewiele ponad 40\% flory miejskiej Olsztyna. Wśród antropofitów dominują diafity, czyli gatunki nie zadomowione trwale. Stanowią one prawie $20 \%$ całej flory synantropijnej Olsztyna. Udział archeofitów (gatunki przybyłe $\mathrm{w}$ czasach przedhistorycznych i w średniowieczu - przed XV wiekiem) i kenofitów (gatunki przybyłe po XV wieku) wynosi odpowiednio $13 \%$ i $11 \%$.

Na obszarze miasta stwierdzono występowanie 74 gatunków archeofitów, co stanowi niewiele ponad $10 \%$ całej flory miejskiej Olsztyna (ryc. 3.). Najczęściej na terenie miasta występują Atriplex patula (83 stanowiska, 178 notowań), Matricaria maritima subsp. inodora (83 stanowiska, 159 notowań), Capsella bursa-pastoris (80 stanowisk, 202 notowania), Cichorium intybus (74 stanowiska, 133 notowania), Fallopia convolvulus (74 stanowiska, 138 notowań) oraz Scleranthus annuus (74 stanowiska, 140 notowań). Dominującą formą życiową wśród archeofitów są terofity. Reprezentowane są one przez 51 gatunków i stanowią ponad $80 \%$ całej flory archeofitów. Drugą co do liczebności formą są rośliny naziemnopączkowe, czyli hemikryptofity. Zaledwie 1\% udział (po jednym gatun$\mathrm{ku}) \mathrm{W}$ grupie archeofitów posiadają chamefity zielne i geofity.

W skład flory miejskiej Olsztyna wchodzą również 64 gatunki kenofitów, stanowiące zaledwie $11 \%$ całej zbadanej flory (ryc. 3.). Spośród wszystkich kenofitów ponad 60\% (41 gatunków) stanowią hemiagriofity, tj. gatunki zadomowione $\mathrm{w}$ zbiorowiskach półnaturalnych, najliczniej reprezentowane przez takie gatunki jak Solidago altissima, Medicago x varia, Erigeron annuus czy Impatiens parviflora. Epekofity, to jest gatunki zadomowione wyłącznie w zbiorowiskach segetalnych i ruderalnych, w liczbie 23 gatunków, stanowią 36\% i są reprezentowane najczęściej przez Chamomilla suaveolens, Conyza canadensis, Galinsoga ciliata i G. parviflora. Wśród kenofitów wyraźnie przeważają gatunki pochodzące z kontynentu europejskiego i północnoamerykańskiego (ryc. 5.). Stanowią one odpowiednio $41 \%$ i $40 \%$. Udział gatunków azjatyckich wynosi $16 \%$, natomiast taksonów pochodzenia antropogenicznego zaledwie $3 \%$.

Dominującymi formami życiowymi wśród kenofitów są hemikryptofity i terofity, które stanowią odpowiednio 39 i 36\%. Najmniejszy udział stanowią chamefity zielne - tylko $1 \%$.

$\mathrm{Na}$ badanym terenie zidentyfikowano 104 gatunki diafitów, co stanowiło prawie $20 \%$ całej flory miejskiej Olsztyna (ryc. 3.). Niemal wszystkie diafity, bo aż 99\% (103 gatunki), należą do ergazjofigofitów - roślin uprawianych przez człowieka i przejściowo dziczejących. Najliczniej są one reprezentowane przez takie gatunki, jak: Lonicera xylosteum, Alcea rosea, Parthenocissus quinquefolia czy Cerastium tomentosum. Do efemerofitów, to jest tylko przejściowo zawlekanych roślin obcego pochodzenia, zaliczono tylko jeden gatunek - Cynodon dactylon. Dominującą formą życiową wśród diafitów są terofity, które reprezentowane są przez 33 gatunki i stanowią niewiele ponad 30\% całej flory diafitów. Drugą co do liczebności formą są hemikryptofity, stanowiące 25\% (26 gatunków).

Analizując przestrzenne rozmieszczenie i występowanie poszczególnych gatunków roślin w wydzielonych na terenie miasta kompleksach zagospodarowania terenu największą liczbę gatunków stwierdzono w kompleksie transportowym. W obrębie tego kompleksu występuje 466 gatunków (9560 notowań), co stanowi 81\% wszystkich zidentyfikowanych taksonów (ryc. 6.).

Tak wysoki udział gatunków w tym typie użytkowania przestrzeni wiąże się z dużą częstością występowania tego typu siedlisk na terenie miasta. Najliczniejszą grupę stanowią tutaj apofity leśne i zaroślowe (24,7\%, 115 gatunków), apofity łąkowe $(17,2 \%, 80$ gatunków) oraz archeofity $(13,9 \%$, 65 gatunków). Najczęstszymi gatunkami były tutaj: Taraxacum officinale, Plantago major, Poa annua, Artemisia vulgaris oraz Polygonum aviculare, Atriplex patula, Matricaria maritima, Capsella bursa-pastoris. Najmniejszy, zaledwie 0,2-procentowy udział, stanowiły występujące tylko w obrębie tego kompleksu efemerofity reprezentowane przez jeden gatunek - Cynodon dactylon, zlokalizowany na trzech stanowiskach. We wszystkich typach użytkowania przestrzeni na terenie miasta stwierdzono wyraźną dominację jednej formy życiowej 
- hemikryptofitów. Ich procentowy udział wahał się od 43\% w kompleksie luźnej (blokowej) zabudowy (121 gatunków) i parku (64 gatunki) do 61\% na lotnisku. Nieco mniej licznie reprezentowane były terofity, a ich udział zawierał się w granicach od $20 \%$ na lotnisku do $35 \%$ w kompleksie rolniczym.

Hemerobia obejmuje stopniowany typ reakcji roślinności na antropopresję, czyli oddziaływanie człowieka, przez co możliwe staje się określenie nasilenia synantropizacji flory i roślinności będącej reakcją na określone natężenie, rodzaj i częstotliwość antropopresji. Największą liczbę gatunków zanotowano w obrębie biotopów reprezentujących stopień przejściowy H4, czyli na siedliskach mezodo $\beta$-euhemerobowych. W obrębie tego typu siedlisk zanotowano występowanie 443 gatunków, co stanowi $76 \%$ wszystkich zidentyfikowanych gatunków (tab. 4.).

Niewiele mniej, bo 401 gatunków i prawie ich 70. procentowy udział zaobserwowano na siedliskach $\beta$-euhemerobowych. Prawie połowa gatunków (284 taksonów, 49\%) zajmuje biotopy mezohemerobowe. Podobny udział gatunków (ok. 200) stwierdzono w obrębie siedlisk $\alpha$-euhemerobowych oraz przejściowych między $\alpha$-euhemerobowymi a polyhemerobowymi. Najmniej gatunków - 155 - zaobserwowano na siedliskach polyhemerobowych.

Tabela 4.

Udział gatunków na siedliskach o różnym stopniu przekształcenia (hemerobi)

Share of species on habitats with different degrees of transformation (hemeroby)

\begin{tabular}{|c|c|c|c|c|c|c|c|c|c|c|c|c|c|c|}
\hline & \multicolumn{14}{|c|}{$\begin{array}{c}\text { STOPIEŃ HEMEROBII } \\
\text { DEGREE OF HEMEROBY }\end{array}$} \\
\hline & \multicolumn{2}{|c|}{ H3 } & \multicolumn{2}{|c|}{ H4 } & \multicolumn{2}{|c|}{ H5 } & \multicolumn{2}{|c|}{ H6 } & \multicolumn{2}{|c|}{ H7 } & \multicolumn{2}{|c|}{ H8 } & \multicolumn{2}{|c|}{ H9 } \\
\hline & $\begin{array}{l}\text { liczba } \\
\text { number }\end{array}$ & $\%$ & $\begin{array}{l}\text { liczba } \\
\text { number }\end{array}$ & $\%$ & $\begin{array}{l}\text { liczba } \\
\text { number }\end{array}$ & $\%$ & $\begin{array}{l}\text { liczba } \\
\text { number }\end{array}$ & $\%$ & $\begin{array}{l}\text { liczba } \\
\text { number }\end{array}$ & $\%$ & $\begin{array}{l}\text { liczba } \\
\text { number }\end{array}$ & $\%$ & $\begin{array}{l}\text { liczba } \\
\text { number }\end{array}$ & $\%$ \\
\hline Gatunki & 284 & 48,9 & 443 & 76,6 & 401 & 69,5 & 169 & 29,5 & 203 & 35,1 & 199 & 34,4 & 155 & 26,7 \\
\hline Notowania & 2359 & 15,8 & 5577 & 37,3 & 2961 & 19,8 & 430 & 2,9 & 839 & 5,6 & 1167 & 7,8 & 1617 & 10,8 \\
\hline
\end{tabular}

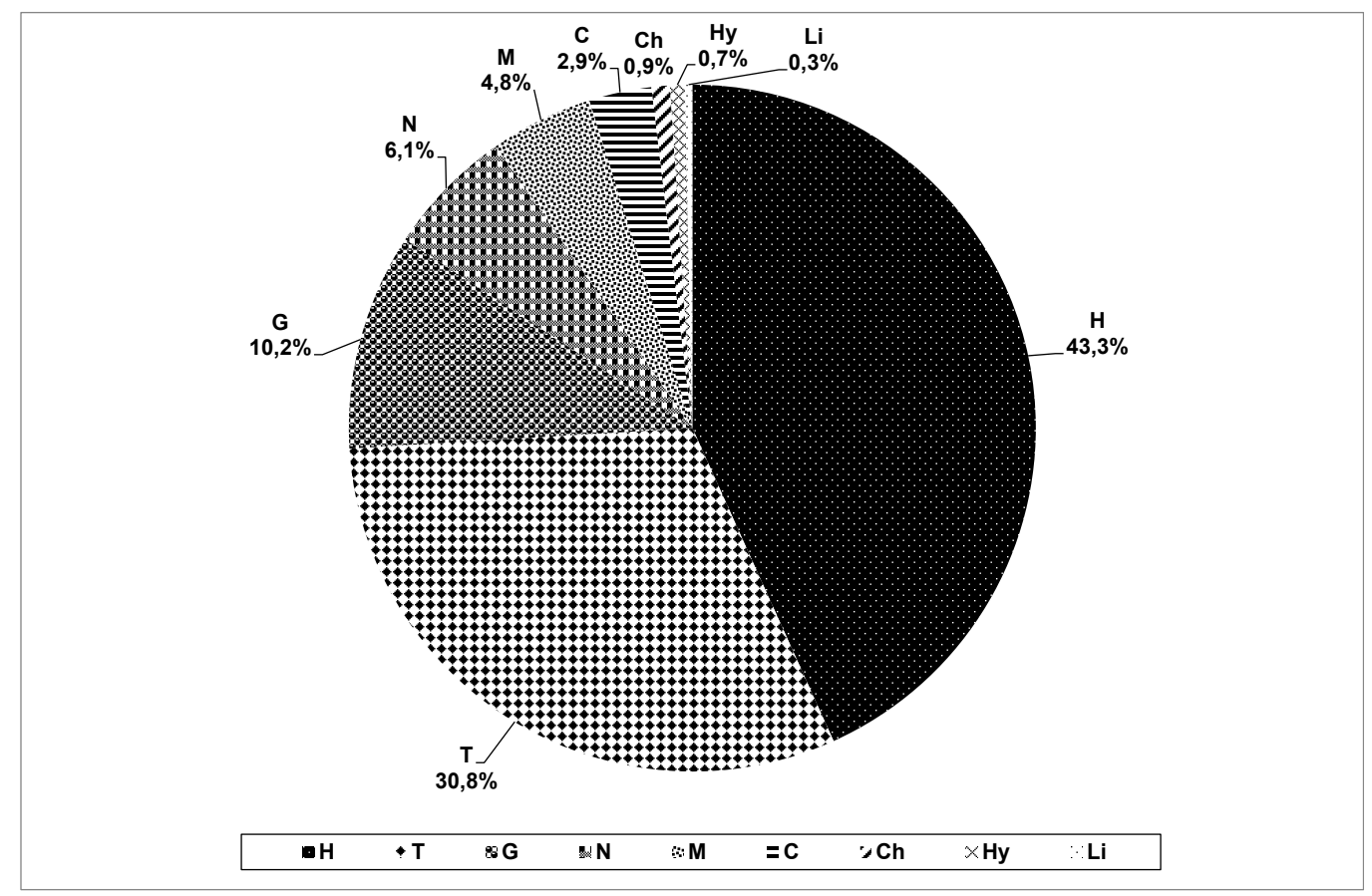

Ryc. 2. Procentowy udzial form życiowych we florze miejskiej Olsztyna (H - hemikryptofity, T - terofity, G - geofity, N - nanofanerofity, M - megafanerofity, C - chamefity zielne, Ch - chamefity drzewiaste, Hy - hydrofity, Li - liany).

Fig. 2. Percentage share of life forms in the urban flora of Olsztyn $(\mathrm{H}$ - hemicryptophytes, $\mathrm{T}$ - therophytes, $\mathrm{G}-$ geophytes, $\mathrm{N}$ - nanofanerophytes, M - megafanerophytes, C - herbaceous chameophytes, $\mathrm{Ch}$ - woody chameophytes, Hy - hydrophytes, $\mathrm{Li}$ lianas). 


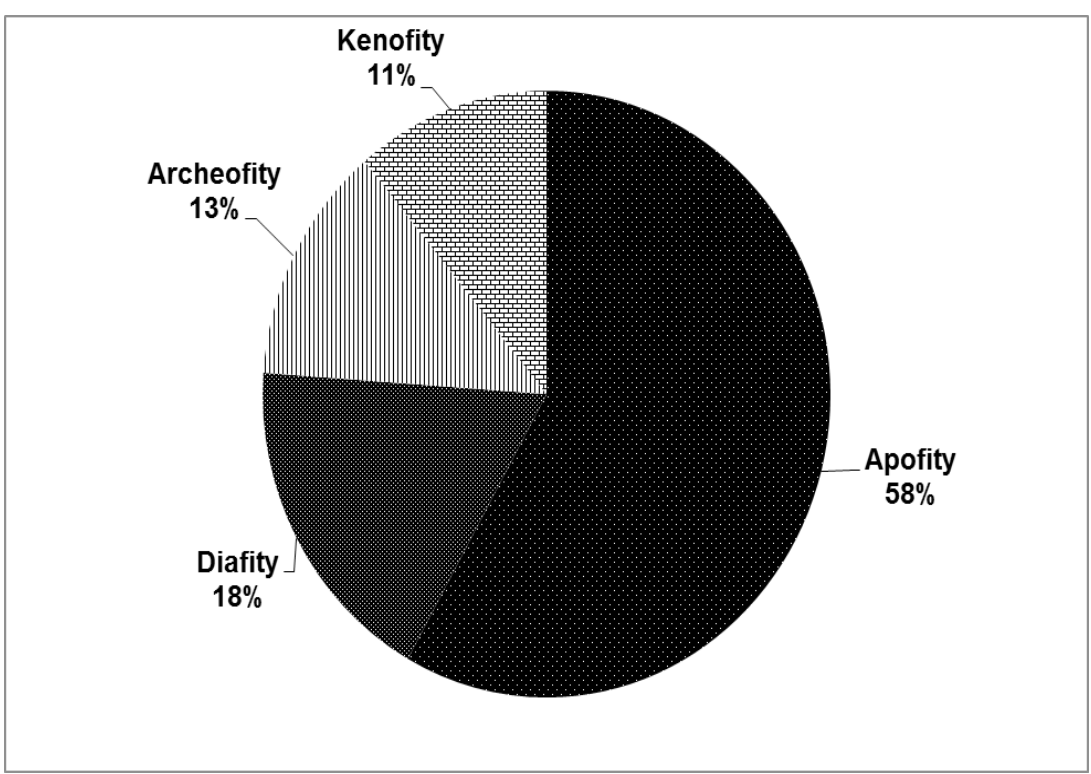

Ryc. 3. Udzial procentowy poszczególnych grup geograficzno-historycznych we florze miejskiej Olsztyna

Fig. 3. Percentage share of particular geographical-historical groups in the urban flora of Olsztyn (Apofity - Apophytes, Archeofity - Archaeophytes, Kenofity - Kenophytes, Diafity - Diaphytes)

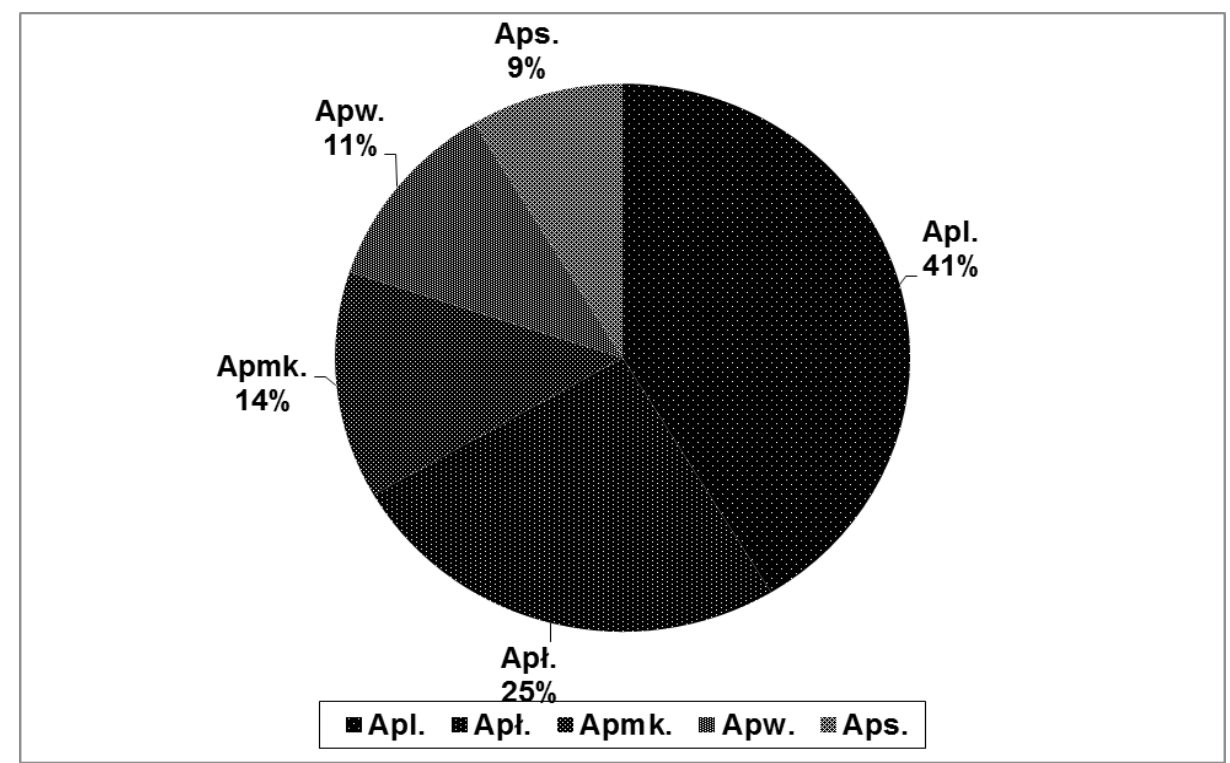

Ryc. 4. Udział poszczególnych grup apofitów we florze miejskiej Olsztyna (Apl - apofity leśne i zaroślowe, Apl - apofity ląkowe, Apmk - apofity muraw kserotermicznych, Apw - apofity nadwodne, Aps. - apofity wydm i piaszczysk).

Fig. 4. The share of particular groups of apophytes in the Olsztyn urban flora (Apl - forest and shrub apophytes, Apl - meadow apophytes, Apmk - xerothermic grassland apophytes, Apw - riparian apophytes, Aps. - Apophytes of dunes and sands). 


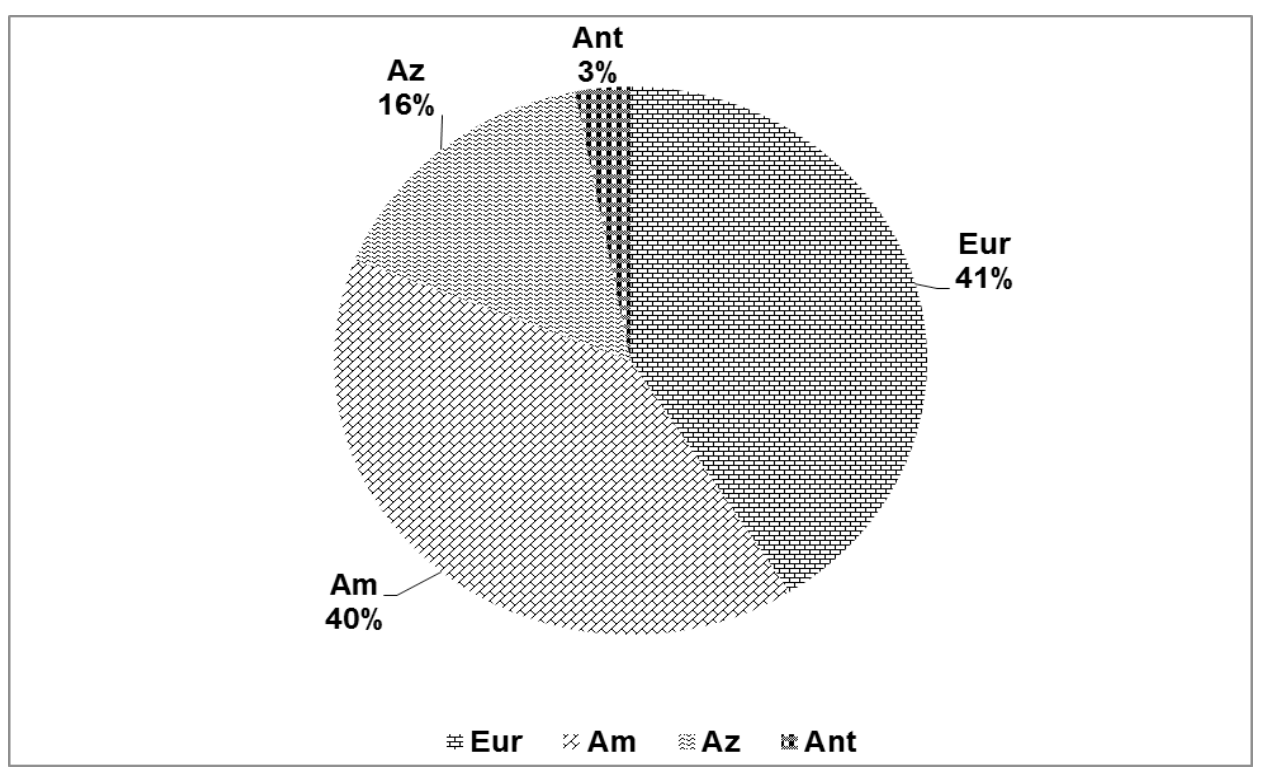

Ryc. 5. Pochodzenie kenofitów na terenie Olsztyna (Eur - gatunki europejskie, Am - gatunki amerykańskie, Az - gatunki azjatyckie, Ant - gatunki antropogeniczne)

Fig. 5. Origin of kenophytes in the Olsztyn area (Eur - European species, Am - American species, Az - Asian species, Ant - anthropogenic species)

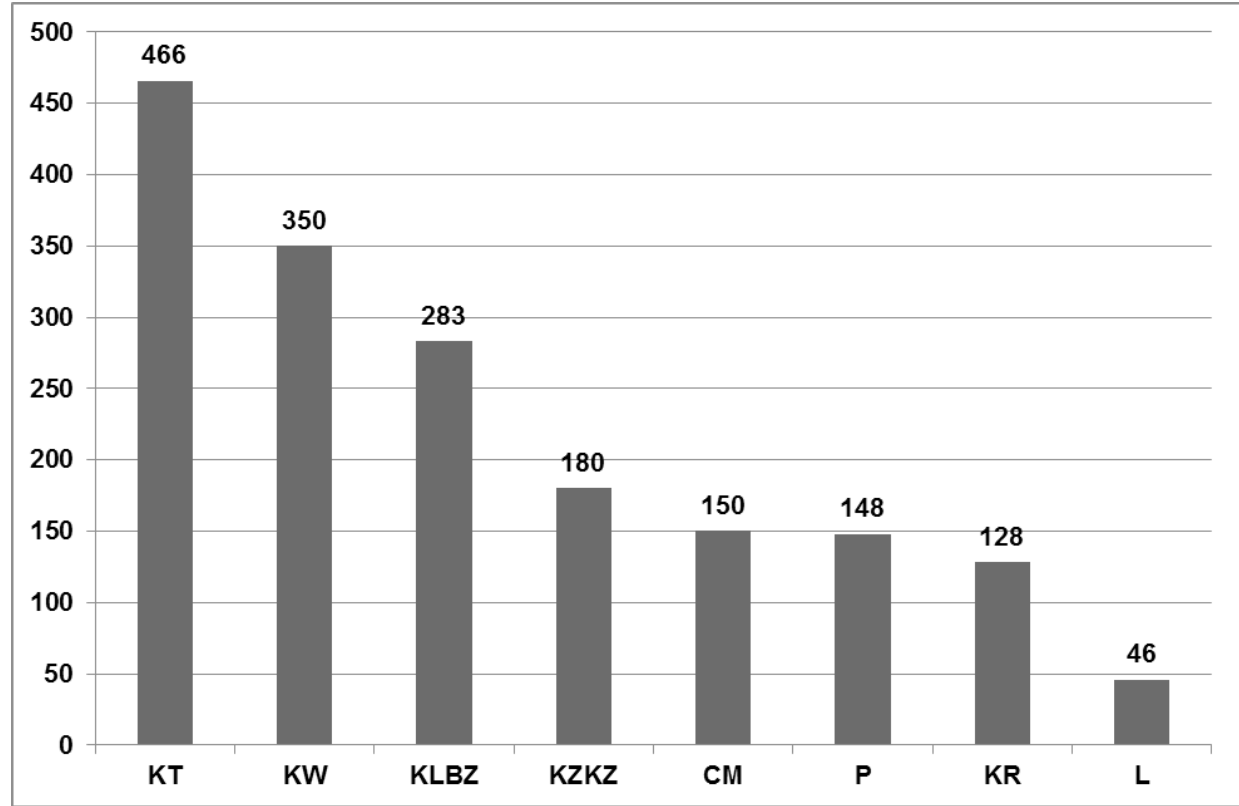

Ryc. 6. Zróżnicowanie liczby gatunków w kompleksach użytkowania przestrzeni (CM - cmentarz, KLBZ - kompleks luźnej (blokowej) zabudowy, KR - kompleks rolniczy, KT - kompleks transportowy, KW - kompleks willowy, KZKZ kompleks zwartej (kamienicznej) zabudowy, L - lotnisko, P - park).

Fig. 6. Variation in the number of species in spatial use complexes (CM - cemetery, KLBZ - loose (block) housing complex, KR - agricultural complex, KT - transport complex, KW - villa complex, KZKZ - compact (tenement) housing complex, L - airport, $\mathrm{P}$ - park). 


\section{Dyskusja}

Badania przeprowadzone $\mathrm{w}$ obrębie biotopów miejskich Olsztyna potwierdziły występowanie 578 gatunków naczyniowych roślin zielnych oraz siewek drzew i krzewów, w tym $5 \mathrm{w}$ randze podgatunku, reprezentujących 83 rodziny i 327 rodzajów. Stanowią one $25,7 \%$ całej flory Polski (Pawłowska 1972).

Zbliżoną do flory biotopów miejskich Olsztyna liczbę gatunków (575) zanotowała Anio1-Kwiatkowska (1974) w mniejszej powierzchniowo Legnicy, a także Sowa (1964) w prawie trzykrotnie większej powierzchniowo, ponad 700-tysięcznej aglomeracji miasta Łodzi - 547 gatunków. W Tarnowie, w mieście najbardziej zbliżonym pod względem powierzchni do Olsztyna, Kucharczyk i Święs (1988) podają 535 gatunków. Dla porównania liczba gatunków notowanych w ponad 1,5 - milionowej Warszawie wynosi 1109 (Sudnik -Wójcikowska 1987), w Poznaniu, liczącym około 600 tysięcy mieszkańców stwierdzono występowanie 900 gatunków (Jackowiak 1993), w Gdańsku i Szczecinie, posiadających po ponad 300 tysięcy mieszkańców, odpowiednio 1030 i 871 gatunków (Schwarz 1967, Ćwikliński 1970). Faliński (1971) szacuje, iż flory roślin naczyniowych w różnych miastach polskich liczą od 300 do 1000 gatunków, a ich bezwzględna liczba nie zależy wprost od powszechnie przyjętych wykładników ich wielkości, tj. zajmowanej powierzchni i od liczby mieszkańców, lecz od dostępności i otwartości miasta dla przenikających do niego gatunków.

Flora synantropijna biotopów miejskich Olsztyna liczy 84 rodziny. Najbardziej zasobnymi w gatunki rodzinami były: Asteraceae, Poaceae, Brassicaceae i Fabaceae. Poczynione porównania wykazały, że we wszystkich przypadkach zestaw rodzin jest zbliżony, jednak ich kolejność nieco odmienna. Najmniejsze różnice wykazują flory Olsztyna i Warszawy. Wśród najliczniejszych w gatunki rodzin w obrębie biotopów miejskich Olsztyna, tj. Asteraceae, Poaceae, Brassicaceae oraz Fabaceae, kolejność czterech pierwszych rodzin jest niemal identyczna jak w przypadku flory miasta Warszawy (Sudnik-Wójcikowska 1987). Przy porównaniu flory Olsztyna z florą Polski zbieżność ta występuje tylko w dwóch pierwszych przypadkach, tj. rodzin Asteraceae i Poaceae (Pawłowska 1972).

Przeprowadzone badania wykazały, że liczebny rozkład taksonów w wydzielonych klasach frekwencji jest zgodny $\mathrm{z}$ uniwersalną prawidłowością: najliczniejszą grupę stanowią taksony bardzo rzadkie, a najmniej liczną taksony pospolite. Analogiczną sytuacje zaobserwował Chmiel (1993) podczas badań nad florą roślin naczyniowych wschodniej części Pojezierza Gnieźnieńskiego i jej antropogenicznych przeobrażeń w wieku XIX i XX.

W spektrum form życiowych badanego tere$\mathrm{nu}$, podobnie jak w innych opracowaniach (m.in. Sudnik-Wójcikowska 1987, Chmiel 1993), dominującą grupą są hemikryptofity.

Spektrum geograficzno-historyczne we florze biotopów miejskich Olsztyna najliczniej reprezentują apofity, czyli rośliny synantropijne miejscowego pochodzenia. Zbliżony udział apofitów potwierdził Wołkowycki (2000) w badaniach flor ruderalnych południowej części Niziny Północnopodlaskiej. Stanowiły one tam 56\% wszystkich stwierdzonych gatunków. Podobny stosunek apofitów do antropofitów zaobserwowano w Polkowicach (Anioł-Kwiatkowska 1974), w Gdańsku (Schwarz 1967) i w Rabce (Skowrońska 1965). Więcej gatunków rodzimych zanotowano w Szczercowie (Sowa, Siciński 1982), Chełmie (Fijałkowski 1963), Warszawie (Sudnik -Wójcikowska 1987), Tarnowie (Kucharczyk, Święs 1988) i w Poznaniu (Jackowiak 1990), gdzie stanowiły ponad $75 \%$ badanej flory. Najmniejszy udział gatunków rodzimych stwierdzono w Jaśle (Święs, Pleban 1981), Wrocławiu (Krawiecowa, Rostański 1976), Stalowej Woli i w Rzeszowie (Kucharczyk, Święs 1988), gdzie stanowiły około $40 \%$. Badania własne nie potwierdzają spostrzeżenia Falińskiego (1971) o mniejszym udziale apofitów w miastach środkowej i wschodniej Polski niż w miastach o zbliżonej wielkości na zachodzie kraju.

Przeprowadzone badania wykazały, że najwięcej gatunków roślin na terenie Olsztyna występuje w kompleksie transportowym. W Poznaniu zdecydowanie najbogatszy był skład gatunkowy flory kompleksu leśno-łąkowego (Jackowiak 1990). W badaniach Olsztyna te naturalne i półnaturalne fitocenozy zostały pominięte.

Rozpatrując typy użytkowania przestrzeni na terenie miasta Olsztyna pod względem stopni hemerobii należy zauważyć, że największą liczbę gatunków na terenie badań zanotowano w obrębie biotopów reprezentujących stopień przejściowy $\mathrm{H} 4$, czyli na siedliskach mezo- do $\beta$-euhemerobowych. Odmienną sytuację zaobserwował we wschodniej części Pojezierza Gnieźnieńskiego Chmiel (1993). Największą liczbę gatunków obserwował on na siedliskach $\alpha$-euhemerobowych. W swoich badaniach przyjął on 6-stopniowy system klasyfikacyjny Sukoppa $(1969,1972)$. 


\section{Wnioski}

1. Flora miejska Olsztyna jest dość uboga i liczy 578 gatunków naczyniowych roślin zielnych oraz samosiewów drzew i krzewów, reprezentujących 84 rodziny.

2. Najliczniej reprezentowaną grupą geograficzno-historyczną we florze biotopów miejskich Olsztyna są gatunki synantropijne miejscowego pochodzenia, czyli apofity, co najprawdopodobniej spowodowane jest mniej intensywnymi procesami synantropizacji i antropofityzacji.

3. Znaczny udział hemikryptofitów i terofitów na terenie zurbanizowanych obszarów miasta Olsztyna może niewątpliwie świadczyć o postępującej synantropizacji flory miasta.

4. Dominacja wśród antropofitów gatunków niezadomowionych trwale (diafitów) przemawia za małą stabilizacją składu flory miasta.

5. Wyraźna liczebna przewaga gatunków roślin w kompleksie transportowym potwierdza znaczącą rolę szlaków komunikacyjnych w dyspersji roślin synantropijnych.

6. Wysoki udział gatunków na siedliskach przejściowych od mezo- do $\beta$-euhemerobowych (4. stopień hemerobii) świadczy o dosyć wąskiej amplitudzie ekologicznej flory miasta.

7. Flora Olsztyna ma charakter typowy dla mniejszych osiedli.

\section{Literatura}

Abromeit J. i in. (1898 - 1940). Flora von Ost- und Westpreussen. Berlin - Königsberg.

Anioł-Kwiatkowska J. (1974). Flora i zbiorowiska synantropijne Legnicy, Lubina i Polkowic. Acta Univ. Wratislav., Wrocław 19: 1-151.

Chmiel J. (1993). Flora roślin naczyniowych wschodniej części Pojezierza Gnieźnieńskiego i jej antropogeniczne przeobrażenia w wieku XIX i XX. Cz. 1, 2. Pr. Zakł. Takson. Roślin UAM Poznań.

Ćwikliński E. (1970). Flora synantropijna Szczecina. Monogr. Bot. 33: $1-103$.

Endler Z., Duriasz J., Juskiewicz B. (1999). Fitocenozy Chelidonio-Robinietum Jurko 1963 w parkach Olsztyna. Biul. Nauk. UWM, Olsztyn, 05: 99 - 108.

Faliński J. (1966a). Degeneracja zbiorowisk roślinnych lasu miejskiego w Iławie. Mater. Zakł. Fitosoc. Stos. UW 13: $1-13$.

Faliński J. (1966b). Antropogeniczna roślinność Puszczy Białowieskiej jako wynik synantropizacji naturalnego kompleksu leśnego. Rozpr. Uniw. Warsz. 13: 1 - 256.

Faliński J. (ed.) (1971). Synanthropisation of plant cover II. Synanthropic flora and vegetation of towns connected with their natural conditions, history and function. Mater. Zakł. Fitosoc. Stos. Uniw. Warsz. 27: 1-317.
Fijałkowski D. (1963). Zbiorowiska roślin synantropijnych miasta Chełma. Ann. University Mariae-CurieSkłodowska Lublin-Polonia, sect. C 18: 291-325.

Jackowiak B. (1990). Antropogeniczne przemiany flory roślin naczyniowych Poznania. Wyd. Nauk. UAM, 42 B.

Jackowiak B. (1993). Atlas rozmieszczenia roślin naczyniowych w Poznaniu. Prace Zakładu Taksonomii Roślin UAM 2, 5-409.

Jackowiak B. (1998). Struktura przestrzenna flory dużego miasta. Studium metodyczno-problemowe. Prace Zakładu Taksonomii Roślin UAM w Poznaniu, Bogucki Wyd. Nauk. Poznań, 8: 1-228.

Jutrzenka-Trzebiatowski A. (1999). Wpływ człowieka na szatę leśną Polski północno-wschodniej w ciągu dziejów. OBN im. Wojciecha Kętrzyńskiego, Olsztyn.

Kalinowska J. (2004). Kształtowanie się fitocenoz wydeptywanych na terenie Olsztyna. Pr. Dokt. UWM, Olsztyn.

Kondracki J. (1988). Geografia fizyczna Polski. PWN, Warszawa.

Kondracki J. (1994). Polska. Mezoregiony fizycznogeograficzne. PWN, Warszawa.

Kondracki J. (2002). Geografia regionalna Polski. PWN, Warszawa.

Kornaś J. (1968a). Prowizoryczna lista nowszych przybyszów synantropijnych (kenofitów) zadomowionych w Polsce. Mater. Zakł. Fitosocjol. Stos. UW 25: 43 - 53.

Kornaś J. (1968b). Geograficzno-historyczna klasyfikacja roślin synantropijnych. Mater. Zakł. Fitosocjol. Stos. UW 25: $33-41$.

Kornaś J. (1977). Analiza flor synantropijnych. Wiad. Bot., 21 (2): $85-91$.

Kornaś J. (1981). Oddziaływanie człowieka na florę: mechanizmy i konsekwencje. Wiadomości Botaniczne 25 (3): 165-182.

Kornaś J., Medwecka-Kornaś A. (2002). Geografia roślin. Wyd. Nauk. PWN, Warszawa.

Korniak T. (1968a). Stanowiska Malva verticillata L. na Pojezierzu Mazurskim. Zesz. Nauk. WSR Olszt. 24 (613): $19-23$.

Korniak T. (1968b). Kilka interesujących gatunków synantropijnych na terenie Pojezierza Mazurskiego. Fragm. Flor. Geobot., 14 (2): 161 - 164.

Krawiecowa A., Rostański K. (1976). Zależność flory synantropijnej wybranych miast polskich od ich warunków przyrodniczych i rozwoju. Acta University Wratislaw., Pr. Bot. 303 (21): 5-61.

Kucharczyk M., Święs F. (1988). An analysis of synanthropic flora of the selected towns of south-east Poland. Symposium Synanthropic flora and vegetation V (ed. by M. Zaliberová), s. 331-336. Martin.

Mirek Z. (1981). Problemy klasyfikacji roślin synantropijnych. Wiad. Bot. 25 (1): $45-54$.

Mirek Z., Piekos-Mirkowa H., Zajac A., Zajac M. (2002). Flowering plants and pteridophytes of Poland. A checklist. 
- Krytyczna lista roslin naczyniowych Polski. W. Szafer Institute of Botany, Polish Academy of Sciences, Kraków.

Nuissl H., Rink D., Steuer P. (2005). The consequences of urban sprawl in a context of decline: the case of Leipzig, UFZ-Diskussionspapiere, No. 7/2005.

Olaczek R. (1982). Synantropization of phytocoenoses. Memor. Zool., 37: 93-112.

Olesiński L. (1968). Spostrzeżenia florystyczne z województwa olsztyńskiego. Fragm. Flor. Geobot., 14 (4): 407 416.

Olesiński L., Korniak T. (1980). Nowe gatunki roślin synantropijnych na Pojezierzu Mazurskim. Fragm. Flor. Geobot., $26(2-4)$.

Pawłowska S. (1972). Statystyka florystyczna Polski. [W:] Szata roślinna Polski. Szafer W., Zarzycki K. (red.). t. 1. PWN, Warszawa: 129 - 131.

Pieczyńska E. (2006). Występowanie i zmienność północnoamerykańskich taksonów z rodzaju Solidago L. na terenie Olsztyna. Pr. Dokt. UWM, Olsztyn.

Schwarz Z. (1967). Badania nad florą synantropijną Gdańska i okolicy. Acta Biol. Med. Soc. Sc. Gedan. 11: 363-494.

Skowrońska W. (1965). Flora synantropijna uzdrowiska Rabki. Fragm. Flor. Geobot. 11: 363-371.

Sowa R. (1964). Roślinność ruderalna Łodzi. Łódzkie Tow. Nauk., Wydz. III - Nauk Matem. Przyr. 96: 1-35.

Sowa R., Siciński J. T. (1982). Flora synantropijna Szczercowa. Spraw. Czyn. Pos. Nauk, Łódź 36: 1-5.

Steffen H. (1931). Vegetationskunde von Ostpreussen. Pflanzensoziologie. Bd. 1, Verlag V. G. Fischer, Jena.

Steffen H. (1940). Flora von Ostpreussen. Königsberg.

Stypinski P. (1978). Drzewa i krzewy cmentarzy Olsztyna. Rocz. Dendrol. 31: 153-161.
Stypinski P. (1980). Występowanie jemioły pospolitej (Viscum album L. ssp. album) na terenie miasta Olsztyna. Rocznik Dendrologiczny, vol. 33:

Stypiński P. (1995). Dendroflora Olsztyna i jej środowisko ekologiczne. Rocznik Dendrologiczny, vol. 43: 79-92.

Sudnik-Wójcikowska B. (1987). Flora miasta Warszawy i jej przemiany w ciągu XIX i XX wieku. Cz. I i II. Wyd. Uniw. Warsz., ss. 242 i 435.

Sukopp H. (1969). Der Einfluss des Menschen auf Vegetation. Vegetatio, 17: 360-371.

Sukopp H. (1972). Wandel von Flora Und Vegetation In Mitteleuropa unter dem Einfluss des Menschen. Ber. ü. Landwirtschaft. Hrsg. Bundesministerium. f. Ernährung, Landwirschaft u. Forsten, 50 (1): 112-139.

Święs F., Pleban A. (1981). Roślinność ruderalna i flora synantropijna miasta Jasło na Pogórzu Karpackim. Ann. Univ. MCS, sec. C, 36: 235-258.

Wołkowycki D. (2000). Różnicowanie i ujednolicanie się flor ruderalnych $\mathrm{w}$ warunkach izolacji środowiskowej. Monogr. Bot. 87: 1-157.

Woś A. (1999). Klimat Polski. Wyd. nauk. PWN, Warszawa.

Zając A., Zając M. (red.) (2001). Atlas Rozmieszczenia Roślin Naczyniowych w Polsce (ATPOL). Prac. Chronologii Komputerowej Inst. Bot. UJ, Kraków.

Zarzycki K., Trzcińska-Tacik H., Różański W., Szeląg Z., Wołek J., Korzeniak U. (2002). Ecological indicator values of vascular plants of Poland. [W:] Z. Mirek (red.), Biodiversity of Poland, vol. 2. - W. Szafer Institute of Botany, Polish Academy of Sciences, Kraków, 183 s.

Zimny H. (2005). Ekologia miasta. Agencja ReklamowoWydawnicza Arkadiusz Grzegorczyk, Stare Babice. 